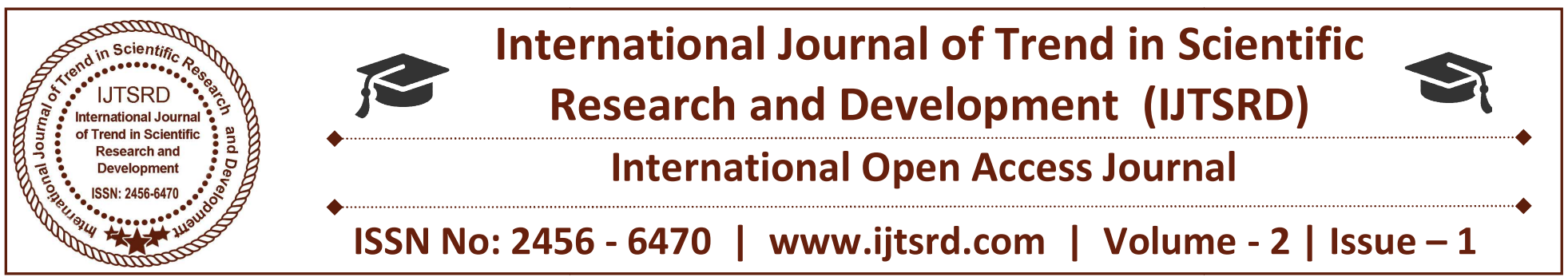

\title{
Corporate Governance under the Provisions of the Companies Act, 2013
}

\author{
CS S Raja Babu \\ BBM, MBA (Fin.), ACS, CMA (Inter.), JM(Company Affairs), \\ D-12, Company Affairs Department, Rashtriya Ispat Nigam Limited, \\ Visakhapatnam Steel Plant, Visakhapatnam
}

\section{ABSTRACT}

Corporate Governance is the set of policies that are created for deciding a company's performance and direction. It is an overview of rules and regulations for the executives of an incorporated firm. They are the ones who agree to take responsibility towards the shareholders. Corporate governance is a broad term in today's business environment. Corporate governance has become a widely-discussed subject and a very important consideration for investors around the world. Investors and governments have started demanding better governance practices from all companies particularly after the wide publicity over corporate scandals such as Enron, Parmalat, Xerox, World Com, Satyam and many others during early parts of this century. The legal outfits of corporate governance can be customized to fit the meticulous choice of each wearer. The paper will discuss the corporate governance under Companies Act, 2013 in theoretical perspective. In addition, it will explain why it is important for any country to follow good corporate governance practices. It discusses on Board composition and Independence, Committees, Disclosures by Directors, Code of Conduct, Role of Independent Directors, Auditors, Duties of Board of Directors, Related Party Transactions, Disclosures in Annual Report, Corporate Social Responsibility etc. The paper gives overall view of the Corporate Governance requirements under Companies act, 2013.

Keyword: Corporate Governance, Companies Act, 2013, Audit Committee, Board of Directors, Independent Directors, Transparency, Accountability and Responsibility

\section{Introduction:}

The word Governance is derived from "gubernate" which means to steer. Corporate or a Corporation is derived from Latin term "corpus" which means a body. Corporate Governance would mean to steer an organization in the desired direction. The responsibility to steer lies with the board of directors/ governing board. Corporate Governance refers to the way a corporation is governed. It is the technique by which companies are directed and managed. It means carrying the business as per the stakeholders' desire. It is actually conducted by the Board of Directors and the committees concerned for the benefit of company's stakeholders. It is all about balancing individual and societal goals, as well as, economic and social goals.

While corporate governance essentially lays down the framework for creating long term trust between companies and the external providers of capital, it would be wrong to think that the importance of corporate governance lies solely in better access of finance.

Corporate governance in India has undergone a paradigm shift by gradually becoming more conscience-driven due to interests of customers, employees, vendors and regulators. With the recent spate of corporate scandals and the subsequent interest in corporate governance, a plethora of corporate governance norms and standards have sprouted around the globe. The Sarbanes Oxley Legislation in the USA, the Cadbury Committee recommendations for European companies and the 
OECD principles of corporate governance are perhaps the best known among these. Corporate Governance Practices are just a little over a decade old and mostly focused on listed public companies.

The Companies Act, 2013 was passed by the Rajya Sabha on $8^{\text {th }}$ August 2013 paving way for a new Company Law and received the assent of the president on 29 $9^{\text {th }}$ August, 2013. The Act, 2013 replaces the existing Companies Act, 1956 which was enacted 57 years ago. The new Act seeks to usher in more transparency and governance in the corporate bodies besides creating the necessary environment for growth in the present global structure. It has the potential to be a historic milestone, as it aims to improve corporate governance, simplify regulations, enhances the interests of minority investors and for the first time states the role of whistle-blowers. The Act encourages good governance practices by placing the onus on independent directors to bring oversight in the functioning of the Board and protect the interest of minority shareholders.

\section{The study has been geared towards achieving the following objectives:}

1. To understand the concept of Corporate Governance.

2. To examine Corporate Governance Rules under Companies Act, 2013

3. To analyse various developments and present framework in Corporate Governance in India.

4. To disseminate information about the latest happenings in the Corporate Governance field to people engaged in policymaking, policy analysis, policy research and other Stakeholders.

5. To provide information for future research works on Corporate Governance

\section{Research Methodology:}

The research paper is an attempt of exploratory research, based on the secondary data sourced from journals, magazines, articles and media reports. Looking into requirements of the objectives of the study the research design employed for the study is of descriptive type. Keeping in view of the set objectives, this research design was adopted to have greater accuracy and in depth analysis of the research study.
Available secondary data was extensively used for the study. The investigator procures the required data through secondary survey method. Different news articles, Books and Web were used which were enumerated and recorded.

\section{Literature Review:}

\section{Definitions of Corporate Governance:}

Corporate Governance, by the very nature of the concept cannot be exactly defined. However there can be no two opinions that "effective accountability to all shareholders is the essence of corporate governance."

"Corporate Governance is concerned with the way corporate entities are governed, as distinct from the way businesses within those companies are managed. Corporate governance addresses the issues facing Board of Directors, such as the interaction with top management and relationships with the owners and others interested in the affairs of the company." Robert Ian (Bob) Tricker (who introduced the words corporate governance for the first time in his book in 1984)

"Corporate Governance is about promoting corporate fairness, transparency and accountability." - James

\section{Wolfensohn (Ninth President World Bank).}

"Corporate governance structure specifies the distribution of rights and responsibilities among different participants in the company such as board, management, shareholders and other stakeholders; and spells out the rules and procedures for corporate decision-making. By doing this, it provides the structure through which the company's objectives are set along with the means of attaining these objectives as well as for monitoring performance."

\section{$>$ Organization for Economic Co-operation and Development (OECD)}

"Corporate governance deals with laws, procedures, practices and implicit rules that determine a company's ability to take informed managerial decisions vis-à-vis its claimants - in particular, its shareholders, creditors, customers, the State and employees. There is a global consensus about the objective of good corporate governance: maximising long-term shareholder value." 
$>$ Confederation of Indian Industry (CCI)

Desirable Corporate Governance Code (1998)

"Corporate Governance is the acceptance by management of the inalienable rights of shareholders as the true owners of the corporation and of their own role as trustees on behalf of the shareholders. It is about commitment to values, about ethical business conduct and about making a distinction between personal and corporate funds in the management of a company."

\section{$>$ Report of N. R. Narayana Murthy Committee}

"Corporate Governance is the application of best management practices, compliance of law in true letter and spirit and adherence to ethical standards for effective management and distribution of wealth and discharge of social responsibility for sustainable development of all stakeholders."

\section{Institute of Company Secretaries of India(ICSI)}

Four Pillars of Corporate Governance:

Corporate Governance is managing, monitoring and overseeing various corporate systems in such a manner that corporate reliability, reputation are not put at stake. Corporate Governance pillars on transparency and fairness in action satisfying accountability and responsibility towards the stakeholders.

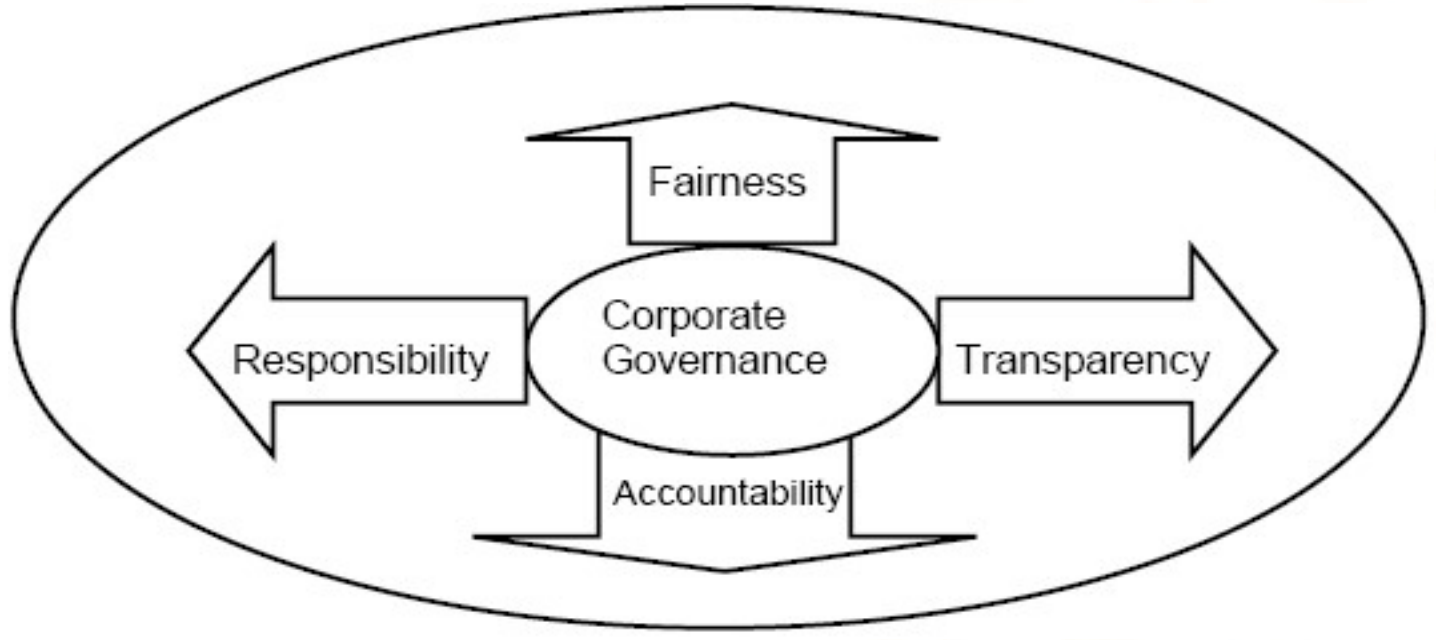

Figure - 1 Four Pillars of Corporate Governance

\section{Corporate Governance under the provisions of Companies Act, 2013: \\ shareholders through a special resolution in the General Meeting.}

The Companies Act, 2013 focuses on good corporate governance practices by increasing the roles and responsibilities of the Board, protecting shareholders' interest and bringing in a disclosure based regime. The 2013 Act significantly changes the way companies are governed. The main provisions related to corporate governance that has been incorporated in the Companies Act, 2013 are under the following:

\section{1) Board structure and functioning:}

\section{A) Company to have Board of Directors (Sec. 149):}

The Companies Act, 2013 provides that a public as well as a private company can have a maximum of fifteen directors on the Board and appointing more than fifteen directors would require approval of
It also provides for appointment of at least one woman director on the Board for such class or classes of companies as may be prescribed. The Act makes it mandatory for a company to have minimum one director who has stayed in the country for a period of 182 days in the previous calendar year.

B) Number of Directorships (Sec. 165):

As per the provisions of the Companies Act, 2013, a person cannot become a director in more than 20 companies instead of 15 as provided in the Companies Act 1956 and out of this 20, he cannot be director of more than 10 public companies.

C) Independent Directors (Sec. 149): 
The meaning of the term independent director given in the Companies Act, 2013 contains most of the attributes of the listing agreement. An independent director should be a person of integrity and possess relevant expertise and experience. The Act states that independent directors should not have any material pecuniary relationship with the company, its promoters, directors and subsidiaries which can affect the independence of the director either in the current financial year or immediately preceding two years. The Act provides for the following provisions with respect to Independent directors:

\section{The Companies Act, 2013 states that}

- Every listed company will have at least one-third of total number of directors as independent directors, with any fraction to be rounded off as one.

- Certain class of companies that meet the criteria listed below are required to have atleast 2 (two) independent directors:

i. Public companies which have paid up share capital of INR 100,000,000 (Rupees Ten Crores only);

ii. Public companies which have a turnover of 1,000,000,000 (Rupees Hundred Crores only); and

iii. Public companies which have, in the aggregate, outstanding loans, debentures and deposits exceeding INR 500,000,000 (Rupees Fifty Crores only)

- The Act, 2013 requires that every independent director should at the first meeting of the Board in which he participates as a director and thereafter at the first meeting of the Board in every financial year or whenever there is any change in the circumstances which may affect his status as an independent director, give a declaration that he meets the criteria of independence.

- The Act provides for the selection of independent director from a data bank maintained by an association, body or institute or as per the specification of the Central government.

- The independent director is not entitled to any stock options in the company.

- No independent director should hold office for more than two consecutive terms of five years each.
D) Code of conduct for independent directors:

Schedule IV of the Act provides for a Code for Independent Directors which an independent director needs to follow. "Code for independent directors" contains detailed guidelines for professional conduct, roles and responsibilities. It covers the following aspects:

- Professional Conduct;

- Seek clarification of information;

- Safeguard the interests of all stakeholders;

- Exercise duties and responsibilities in a bona fide manner; and

- Evaluation of the performance of board and management etc.

\section{E) Liabilities of independent director:}

Under the Companies Act, 2013, an independent director and a non-executive director not being promoter or KMP, will be held liable, only in respect of such acts of omission or commission by a company, which had occurred with his knowledge, attributable through board processes, and with his consent or where he had not acted diligently.

\section{F) Duties of directors (Sec. 166):}

For the first time, duties of directors have been defined in the Act. The Act considerably enhances the roles and responsibilities of the Board of Directors and makes them more accountable. The Act, 2013 has set out the following duties of directors:

- To act in accordance with company's articles;

- To act in good faith to promote the objects of the company for the benefit of the members as a whole, and the best interest of the company, its employees, shareholders, community and for protection of the environment;

- To exercise duties with reasonable care, skill and diligence, and exercise of independent judgment;

The director shall not:

- Involve in a situation in which he may have direct or indirect interest that conflicts, or may conflict, with the interest of the company;

- Achieve or attempt to achieve any undue gain or advantage, either to himself or his relatives, partners or associates.

- Assign his office and any assignment so made shall be void.

\section{G) Board's Report:}

Section 134 of the Act seeks to make the board's report more comprehensive by inserting disclosures to 
bring transparency in the functioning of the Board. Important disclosures include:

1. Extract of the Annual Return;

2. Number of meetings of the Board;

3. Directors' Responsibility Statement;

4. A statement on declaration by the independent directors;

5. Company's Policy on directors' appointment and remuneration including criteria for determining qualifications, positive attributes, independence of a director and other matters provided under Sec. 178 ;

6. Explanations or comments by the Board on every qualification, reservation or adverse remark or disclaimer made in Statutory Auditors Report and Secretarial Audit Report;

7. Particulars of loans, guarantees or investments;

8. Particulars of Contracts or arrangements with related parties referred under Sec. 188;

9. The state of the Company's Affairs;

10. The amounts, if any, which it proposes to carry to any reserves;

11. Dividend details

12. Material Changes and commitments, if any, affecting the financial position of the company.

13. The Conservation of Energy, technology absorption, foreign exchange earnings and outgo;

14. Development and implementation of risk management policy for the company;

15. CSR Policy and initiatives taken during the year;

16. The details of directors/ key managerial personnel who were appointed or have resigned during the year;

17. The names of companies which have become ceased to be its Subsidiaries, Joint Ventures or associate companies during the year.

18. The details of deposits, covered/ are not in compliance with Chapter V of the Act.

19. The details in respect of adequacy of internal financial controls with reference to financial statements.

20. The details of significant and material orders passed by the regulators or courts or tribunals impacting the going concern status and company's operations future.

A signed copy of financial statements including consolidated financial statements shall be issued, circulated or published along with a copy each of Notes to financial Statements, Auditor's Report and Board's Report.
H) BOARD MEETINGS (173):

Every Company shall hold a Minimum No. of 4 meetings of Board of Director in every year in such manner that not more than 120 days shall intervene between two consecutive meetings of the Board.

a) Calling of Meeting: Meeting of Board of Director should be called by giving 7 days notice to every Director at his registered address through by hand delivery or by post or by electronic means. The notice of the meeting shall, inform regarding the option available to participate through video conferencing mode and provide all the necessary information to enable the directors to participate through video conferencing.

b) Convening of Board Meetings thru Video Conferencing: Conducting and participation of Board Meetings through Video Conferencing or other audio visual means is recognized, provided such participation is recorded and recognized. Recording and storing of the proceedings of the meetings along with date and time is compulsory. The provision of conducting the Board Meeting thru Video Conferencing would bring in more ease to the Board's functioning.

c) Shorter Notice: A meeting of Board of Directors can be called by shorter notice to transact urgent business subject to the condition that at least one Independent Director shall be present at the meeting.

d) Quorum: The quorum for a Meeting of Board of Directors of Company shall be one-third of its total strength or two directors, whichever is higher. Director participating in a meeting through video conferencing or other audio visual means shall be counted for the purpose of quorum.

\section{J) Annual General Meeting (Sec.96):}

Every company other than a One Person Company shall in each year hold in addition to any other meetings, a general meeting as its annual general meeting A Company may hold its first AGM within the period of 9 months from closing of its first financial year otherwise in other cases within the period of 6 months. Every annual general meeting shall be called during business hours, that is, between 9 a.m. and 6 p.m. on any day that is not a National Holiday and shall be held either at the registered office of the company or at some other place within 
the city, town or village in which the registered office of the company is situate. A notice of 21 days has to be sent to all members in this regard.

K) Secretarial Standards (Sec.205): Company Secretary of the Company shall ensure that the
Company complies with the applicable Secretarial Standards. Presently, every company shall comply Secretarial Standard on Board Meetings (SS-1) \& Secretarial Standards on General Meetings are issued by ICSI.

\section{2) Committees of Board:}

The Act, 2013 envisages 4 (four) types of committees to be constituted by the board:

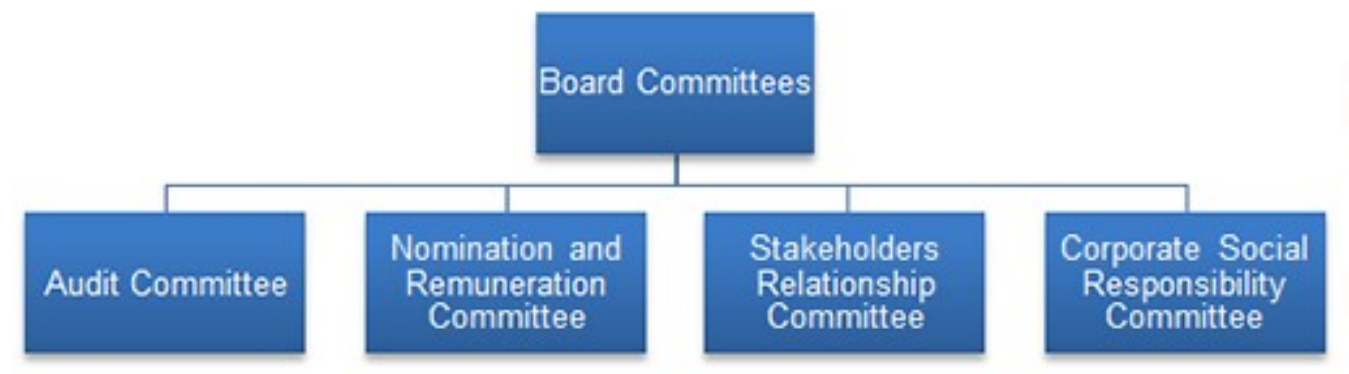

\section{A) Audit Committee:}

Section 177 of the Companies Act, 2013 makes audit committees mandatory for listed companies and certain class of companies that meet the criteria listed below:

i. Public companies which have paid up share capital of INR 100,000,000 (Rupees Ten Crores only);

ii. Public companies which have a turnover of 1,000,000,000 (Rupees Hundred Crores only); and

iii. Public companies which have, in the aggregate, outstanding loans, debentures and deposits exceeding INR 500,000,000 (Rupees Fifty Crores only)

The Act provides that audit committee should consist of minimum of three directors with independent directors forming majority. The 1956 Act did not prescribe any academic or professional qualifications for directors. The 2013 Act provides that majority of members of Audit Committee including its Chairperson shall be persons with ability to read and understand the financial statements.

The role of the audit committee includes the following activities as per the 2013 Act:

- The recommendation for appointment, remuneration and terms of appointment of auditors of the company;

- review and monitor the auditor's independence and performance, and effectiveness of audit process;

- examination of the financial statement and the auditors' report thereon;
- approval or any subsequent modification of transactions of the company with related parties;

- scrutiny of inter-corporate loans and investments;

- valuation of undertakings or assets of the company, wherever necessary;

- evaluation of internal financial controls and risk management systems;

- Monitoring the end use of funds raised through public offers and related matters; and

- Authority to investigate into any matter in relation to the items specified above or any such matter referred to it by the Board.

\section{B) Nomination and Remuneration Committee:}

Section 178 of The Act, 2013 requires all listed companies and other prescribed classes of companies mentioned in $4.2 \mathrm{~A}$ ) of this report are to constitute Nomination and Remuneration Committee that formulates the criteria for selection of the directors, a policy relating to the remuneration for the directors, Key Managerial Personnel and other employees. Such committee should consist of three or more nonexecutive directors and at least one-half of the members should be independent directors.

\section{C) The Corporate Social Responsibility (CSR) Committee:}

Section 135 of the Act, 2013 requires every Company having net worth of Rs. 500 Crores or more, or turnover of Rs. 100 Crores or more, or a net profit of Rs. 5 Crores or more during any financial year, should constitute a Corporate Social Responsibility Committee of the Board, consisting of minimum of three directors. The CSR Committee should consist of 
a minimum of one independent director. The CSR committee should formulate, monitor and recommend the CSR policy to the Board. Board has to approve CSR policyand recommend the amount of expenditure to be incurred on the CSR activitiesand disclose the CSR contents in the board's report and place CSR Policy on the company website.

\section{D) Stakeholders Relationship Committee (Sec. 178):}

The Act protects all security holders in addition to equity investors. It requires that a company with more than 1000 shareholders, debenture holders, deposit holders and other security holders at any time during the financial year shall constitute a Stakeholders Relationship Committee. It will be chaired by a nonexecutive director and consist of such other members as may be decided by the board. The committee will consider and resolve the grievances of security holders of the company.

\section{3) Audit and Auditors}

\section{A) Internal Audit:}

The Act, 2013 provides companies of certain class as prescribed to appoint an internal auditor for internal auditing on the functions and activities of the company. The board should either appoint Chartered Accountant or Cost Accountant or any other professional for carrying internal audit. The Central government has the authority to prescribe the manner and the time period in which the audit will be conducted and the structure of reporting the same to the board.

\section{B) Appointment of auditors}

Under the Companies Act, 2013 a company will appoint auditor at its first Annual General Meeting and the auditors appointed will hold its office till the conclusion of the sixth Annual General Meeting. Though the auditor will be appointed for five years the matter relating to such appointment will be placed for ratification at each Annual General Meeting. Auditors have to report to central government any offence involving fraud being committed against the company by its officer or employee.

\section{C) Rotation of auditors}

Section 139 of the Companies Act of 2013 provides for compulsory rotation of individual auditors and of audit firm. No listed company or a company belonging to such class or classes of companies as may be prescribed, should appoint or reappoint an individual as auditor for more than one term of five consecutive years; and an audit firm as auditor for more than two terms of five consecutive years.

\section{D) Responsibilities of an auditor}

The statutory responsibilities of the auditor fundamentally require the following:

$\checkmark$ To make certain inquiries;

$\checkmark$ To make a report to the company on the accounts examined;

$\checkmark$ To make a proclamation in terms of the provisions set;

$\checkmark$ Detection and Prevention of Fraud;

$\checkmark$ Duty to report fraud; and

$\checkmark$ Duty as to substantial precision.

\section{E) Secretarial Audit (Sec.204)}

Every listed company and other class of Companies as prescribed shall appoint a Secretarial Auditor and shall annex with its Board's Report, a Secretarial Audit Report, given by a Company Secretary in practice. The Board of Directors, in their Report, shall explain in full any qualification or observation or other remarks made by the Secretarial Auditor in his Report.

\section{F) Cost Audit (Sec. 148)}

Central government may direct to conduct cost audit in respect of companies engaged in the production of such goods or providing such services and have a net worth or turnover as may be prescribed. Cost auditor shall be appointed by board whereas remuneration of cost auditor shall be ratified by the members in General Meeting. Cost audit shall be done by cost accountant in practice. After receiving the cost audit report, company shall furnish full information and explanations on every reservations or qualifications to CG within 30 days of receipt of cost audit report.

\section{4) Other important Provisions on Corporate Governance:}

\section{A) Related Party Transactions (RPT) (Sec.} 188):

As per the provisions of the Companies Act, 2013 no company should enter into RPT contracts pertaining to -

a. sale, purchase or supply of any goods or materials;

b. sale or dispose of or buying, property of any kind;

c. leasing of property of any kind;

d. availing or rendering of any services; 
e. appointment of any agent for purchase or sale of goods, materials, services or property;

f. Such related party's appointment to any office or place of profit in the company, its subsidiary company or associate company.

Related Party Transaction can be entered into only if it is approved by a special resolution at the general meeting. A member of the company, who is a related party, cannot vote on such special resolution. The restrictions will not apply to any transactions entered into by the company in its ordinary course of business other than transactions, which are not on an arm's length basis. Every contract or arrangement entered into with a related party shall be referred to in the Board's report along with the justification for entering into such contract or arrangement. The central government may prescribe additional conditions for entering into related party transactions. Further, every RPT shall require the approval of Audit Committee and Board of Directors. Violations of these provisions would be punishable with fine or imprisonment or both.

\section{B) Corporate Social Responsibility (CSR) Sec. 135}

CSR which has largely been a voluntary contribution by corporates has now been included in law. India has become the first country to mandate spend on CSR activities through a statutory provision. The requirement will apply to any company that is incorporated in India, whether it is domestic or a subsidiary of a foreign company. Every Company having net worth of Rs. 500 Crores or more, or turnover of Rs. 100 Crores or more, or a net profit of Rs. 5 Crores or more during any financial year, should constitute a Corporate Social Responsibility Committee of the Board as detailed above.

The Board of every company fall under above criteria shall ensure that the company spends, in every financial year, at least two per cent $(2 \%)$ of the average net profits of the company made during the three immediately preceding financial years, in pursuance of its Corporate Social Responsibility Policy.

It is estimated that a total of 8,000 companies in India would be required to meet the CSR requirements among the 9 lakh active companies in India and the $2 \%$ CSR expenditure would translate to companies' spending around Rs 12,000 crore to Rs. 15,000 crore annually.

\section{C) Prohibition of Insider Trading(Sec.195)}

No person including any director or KMP of a company shall enter into insider trading except any communication required in the ordinary course of business or profession or employment or under any law. Insider trading by any director or key managerial personnel of a company is punishable by imprisonment of up to five years and fine up to Rs. 25 crore or three times the amount of profits made out of insider trading, whichever is higher, or both.

\section{D) Vigil Mechanism (Sec 177(9\&10))}

Every listed company or such class or classes of companies as may be prescribed, shall establish a vigil mechanism. Mechanism shall facilitate directors and employees to report genuine concerns and provide adequate safeguards against victimization of persons who use such mechanism make provision for direct access to the chairperson of the Audit Committee in appropriate and exceptional cases. The details of establishment of Vigil Mechanism shall be disclosed by the Company at its website and in the Board's Report.

\section{E) Constitution of National Financial Reporting Authority (NFRA)}

The Act replaces the "National Advisory Committee on Accounting Standards" with "National Financial Reporting Authority" (NFRA). National Financial Reporting Authority (NFRA) will be the new regulator for Auditors. This authority will have powers to recommend, enforce and monitor compliance of accounting and auditing standards. It will make recommendations to the central government on the formulation of accounting and auditing policies and standards for adoption by companies or class of companies and their auditors. This authority will also have the power to investigate, either suo moto or on a reference made to it by the central government, for such class of bodies corporate or persons, the matters of professional or other misconduct committed by any member or firm of chartered accountants registered under the Chartered accountants Act. No other institute or body will initiate or continue any proceedings in such matters of misconduct where the NFRA has initiated an investigation. 


\section{F) Serious Fraud Investigation office}

The Act, 2013 provides statutory status to SFIO. The central government may assign investigation into the affairs of a company to SFIO (i) on receipt of a report of the registrar or inspector, (ii) on intimation of a special resolution passed by a company that its affairs are required to be investigated, (iii) in public interest, or (iv) on request from any department of the central government or state government. SFIO will have the power to arrest in respect of certain offences, which attract the punishment for fraud. If any case has been assigned by the Central government to SFIO for investigation, no other investigating agency will proceed with investigation in such cases. Stringent penalties are prescribed for fraud related offences.

\section{G) Risk Management Policy}

Every Company shall develop and implement a Risk Management Policy for the Company including identification therein of elements of risk, if any, which in the opinion of the Board many threaten the existence of the Company. Board's Report of the Company shall contain a statement in this regard.

\section{H) Penalties and Punishments}

The Companies Act, 2013 poses various obligations to be discharged by the Companies, Directors, Managers and other Officials to ensure better Corporate Governance practices in Indian Corporates. Non-compliance of such obligations attracts punishment which may be imprisonment and/ or fine/ penalty. The new Companies Act, 2013 has come up with more stringent punishment and penalties for the non- compliance of various provisions of and rules under the Act as compared to the former Companies Act, 1956. Therefore, Companies and other responsible person(s) must look the same for ascertaining the implications of the actions done/ to be done by themselves so that the requisite compliance should be in place within prescribed time which ensures better Corporate Governance in India.

\section{CONCLUSION}

Corporate governance in India has undergone a paradigm shift by gradually becoming more conscience-driven due to interests of customers, employees, vendors and regulators. With the recent spate of corporate scandals and the subsequent interest in corporate governance, a plethora of corporate governance norms and standards have sprouted around the globe. The Sarbanes Oxley legislation in the USA, the Cadbury Committee recommendations for European companies and the OECD principles of corporate governance are perhaps the best known among these. But developing countries have not fallen behind either. Well over a hundred different codes and norms have been identified in recent surveys and their number is steadily increasing.

In the last few years, the thinking on the topic in India has gradually crystallized into the development of norms for listed companies. The problem for private companies, that form a vast majority of Indian corporate entities, remains largely unaddressed. Development of norms and guidelines are an important first step in a serious effort to improve corporate governance. The bigger challenge in India, however, lies in the proper implementation of those rules at the ground level.

Even the most prudent norms can be hoodwinked in a system plagued with widespread corruption. Nevertheless, with industry organizations and chambers of commerce themselves pushing for an improved corporate governance system, the future of corporate governance in India promises to be distinctly better than the past. If practiced in the right spirit, it can lead to unlocking the intellectual power of the board and management to focus organizational efforts on value-creating objectives using ethical means.

Technology, laws and regulations, disruptive events and demand for greater accountability are the business drivers for embracing new governance practices. Moreover, security, identity and access, information rights management, e-mail retention, centrally controlled spreadsheets, management and reporting are the enabling technologies for visionary corporate governance practices.

However, The Companies Act, 2013 was passed by the Rajya Sabha on 8th August 2013 paving way for a new company law and received the assent of the president on 29th August, 2013. The Act, 2013 replaces the existing Companies Act, 1956 which was enacted 57 years ago. The new Act seeks to usher in more transparency and governance in the corporate 
bodies besides creating the necessary environment for growth in the present global structure.

Under the companies Act, 2013, in the context of the better Corporate Governance agenda, the role of the Board becomes extremely critical. Many provisions pertaining to independence of directors, auditors, strict disclosure norms and protection of investors will have wide implications and bring in greater transparency and accountability in the working of the company and at the same time, minimise the incidents of corporate frauds. Its fundamental objective is not mere fulfillment of the requirements of law but in ensuring commitment of the Board in managing the company in a transparent manner for maximizing stakeholder value. The new Act seeks to guide in more transparency and governance in the corporate bodies besides creating the necessary environment for growth in the present global structure. It has the potential to be a historic milestone, as it aims to improve corporate governance, simplify regulations, enhances the interests of minority investors and for the first time mentioned the role of whistle-blowers.

The Act encourages good governance practices by placing the onus on independent directors to bring oversight in the functioning of the Board and protect the interest of minority shareholders. But in true sense, Good corporate governance goes beyond rules and regulations that the Government can put in place. It should come from within, which would enable the organization to establish productive relationship with its internal customers and lasting business relationship with its external customers. The real onus of achieving desired levels of corporate governance lies with corporate themselves and not in external measures.

\section{REFERENCES}

1. Vijaya Batth, Dr. Bhagirathi Nayak, Dr. Pratima Sarangi. (2016). Role of Independent Directors in the Changing Business Scenario in India. Retrieved from http://www.ijsrm.in/v4i2/2\%20ijsrm.pdf

2. Ms. Sunita (2015), Companies Act, 2013: A tool to Strengthen, Vol.1, Issue.11, May 2015, IJMSRR, ISSN- -2349-6738 E- ISSN - 2349-6746

3. Geetika Vijay (2014), “Corporate Governance under the Companies Act 2013: A More Responsive System of Governance", Volume : 4| Issue : 4 | Apr 2014 | ISSN - 2249-555X
4. Discussion paper on Corporate Governance In India : Theory \& Practice : National Foundation for Corporate Governance (2004)

5. Companies Act - 2013 New Rules of The game, A Deloitte and ASSOCHAM Report

\section{Books:}

1. eMinds legal (2014), "Companies Act, 2013 Simplified" Bharat Law House Pvt. Ltd. New Delhi, India

2. Sharma JP (2014), "Governance, Ethics and Social Responsibility of Business" Ane Books Pvt. Ltd. New Delhi, India.

3. Kuchhal MC (2013), "Modern Indian Company Law" Shree Mahavir Book Depot (Publishers), New Delhi, India.

\section{Bare Acts:}

Companies Act, 1956.

$>$ Companies Act, 2013

$>$ DPE Guidelines on Corporate Governance, 2010

$>$ Secretarial Standard $-1 \& 2$ issued by the Institute of Company Secretaries of India

\section{WEBSITES}

1. http://www.caclubindia.com

2. https://taxguru.in/company-law/

3. http://www.kpmg.com

4. http://www.kpmg.com/IN/en/Documents/KPMG_ Companies_Act_2013.pdf

5. https://www.pwc.in

6. https://www.pwc.in/en_IN/in/assets/pdfs/publicati ons/2013/companies-act-2013-Key-highlightsand-analysis.pdf

7. www.mca.gov.in

8. www.icsi.edu

9. www.dpe.nic.in

10. www.icai.org

11. www.icmai.in 